III.--The President's Address: Some Ideas on Life.

By HENRx WOODWARd, LL.D. F.R.S.

(Delivered January 21st, 1903.)

THOSE who have in infancy been properly nurtured on a wholesome diet of fairy tales and folk-lore, will carry with them through life, even to old-age, many very pleasant memories of those delightful friends of one's childhood, 'Beauty and the Beast,' 'Cinderella,' 'Little Red Riding-hood,' 'Jack the Giant-killer,' 'Sleeping Benuty,' 'Blue Beard,' and many others; or if they belong to a later generation than myself, they will in early life have been on intimate terms with 'Tom the Water-Baby,' in Kingsley's wonderful book ; or will feel, as most of us do, grateful to "Lewis Carroll" (L. Dodgson) for having written 'Alice in Wonderland' and "Through the Looking-glass," for our delectation. Pleasant indeed are such memories,-like the scent of heather from the hills,-_or "the odour of brine from the ocean."

On Christmas holidays, in passing along the. High Street of the Royal Borough of Kensington, I was startled by a shrill familiar voice from out the distant past, and suddenly, for a few moments, I had sixty years lifted off my shoulders and became once more a child at a school-room window in Norwich, looking on with large eyes at the ineffable effrontery of $\mathrm{Mr}$. Punch encountering the constable, and filled with admiration at the courage and fidelity of his dog Toby.

Perhaps the oldest themes, which are to be found broidered into the later history, legends, and traditions of all races of mankind, are those which relate to the creation of the world and its inhabitants, and their destruction by the flood.

Apart from the sacred writings of the Hebrews, we have Assyrian tablets and Egyptian hieroglyphs, while the Greeks have given us in charming fables, and in many versions, the account of Prometheus forming men of clay and stealing fire from the chariot of the sun to endow them with life; of Deucalion and Pyrrha rescued from the flood, and afterwards renewing the human race by throwing stones behind them which became men; of Epimetheus and his wife Pandora, and the story of the sealed box, which she was forbidden to open, and how the curiosity of Pandora caused her to raise the lid, when all the evils incident to humanity poured out, and the only good remaining was Hope, which has been the solace of mankind ever since. 
But leaving the regions of classical and mediæval myths, and reven passing over unnoticed the earlier writers and philosopherswhose observations, although often very good, ended frequently in the fabulous and mysterious, or were intermingled with gross errors resulting from ignorance of astronomical laws and cosmical and chemical effects-we come, in 1669, to the observations of Steno, a professor of the Padua University, who compared fossil shells with recent, and showed that the two were often specifically the samethat sharks' teeth from the hills of Rome were like those of a shark now living in the Mediterranean.

The eighteenth century gave birth to many able philosophers and also to many writers having a distorted vision resulting from a firm belief in the literal acceptance of the Mosaic cosmogony, into which they constrained their facts and observations to fit.

Gesner, a Swiss observer, in 1759, demonstrated, by comparing past physical changes with those now in progress, that elevation of mountains and the wearing away of ravines and valleys must have occupied tens of thousands of years to accomplish.

[1665-1729.] Dr. John Woodward insisted on the theory that all deposits resulted from the Noachian deluge, and that their materials and fossil-contents were arranged by gravitation, the heaviest at the bottom. He did one excellent thing, he founded in Cambridge the Woodwardian chair of geology, which has now become a great centre for the teaching of modern geology, but was originally designed to ensure the delivery of a sermon annually, to confound the doctrines of Dr. Camerarius of Tubingen and all his works, because he differed from the views of Dr. Woodward.

Some of the writings of the Italian naturalists at this time were most brilliant and advanced, but the lack of frequent intercommunication between men of science 150 years ago prevented the wide spread of intellectual ideas.

Amongst the most able writers in this country (1726-1797) was James Hutton of Edinburgh, whose Theory of the Earth \&c. was the foundation of Lyell's Principles of Geology and many other later writings. His views, based on observations, were clear and convincing to all studious minds:-

"The ruins of an older world are visible in the present structure of our planet; and the strata which now compose our continents have been once beneath the sea, and were formed out of the waste of pre-existing continents. The same forces are still destroying, by chemical decomposition or mechanical violence, even the hardest rocks, and transporting the materials to the sea, where they are spread out and form new strata analogous to those of more ancient date. Although loosely deposited along the bottom of the ocean, they become afterwards altered and consolidated by volcanic heat, and then heaved up fractured and contorted." 
In WILLIAM SMITh (1769-1839) we have a man of humble origin, born at Churchill in Oxfordshire, who, by force of will and industry, trained himself and became a mineral surveyor and geologist of no mean order. He not only mapped out the geology of England and Wales in a most admirable manner, but discovered a great and original principle, which has stood the test of over 100 years of subsequent geological field-work, namely, that the relative age of sedimentary deposits can be determined with certainty by their organised fossil-contents. This principle, which he was able to prove to demonstration over wide areas and in hundreds of instances, together with the excellent map which he produced, obtained for him from Sedgwick the title of "Father of English Geology." Had William Smith been as able a writer as he was a brilliant observer in the field and mapper, his fame would have been more widely known than it is. One of his geological contemporaries was Samuel Woodward* of Norwich (1790-1837). Suffice it to say that with a succession of men like Sedgwick, Conybeare, Buckland, Phillips, Murchison, Lyell, Scrope, Fitton, de la Beche, Griffiths, Portlock, Prestwich, Ramsay, Geikie, geology has progressed enormously in the past 100 years, and is now one of the most popular sciences of the day.

From the birth of orderly stratigraphical geology has arisen the cognate science of Palocontology which treats of all fossil remains, and takes note of their succession in the rocks as well as their zoological position among living organisms.

But since the publication of Darwin's Origin of Species, now forty years ago, a new and ardent school of zoologists and botanists have entered the field of palæontology, who,-whilst they ignore entirely the advantage which the stratigraphical geologist derives from fossils, looked at from the chronological aspect,--are nevertheless eager to possess themselves of the paloeozoological evidence they furnish, which is in fact the key to open the lock of the casket that holds the secret of the origin of species, and even, they believe, of the beginning of life on the earth-a secret they are as eager to learn, as that for which our first mother Eve bartered Paradise, or that which excited the curiosity of the Greek Pandora, or the unhappy wives of Bluebeard.

Although I may not deceive you with promises to disclose the very beginning of life, I may at least be able so far to lift the lid of the casket as to give you a glance at some of the earliest appearances of groups of living organisms, and point out a few which have persisted over vast periods of time, and others which, though of great importance at one time (like some of our celebrated human families), have now entirely disappeared.

* Author of a work entitled 'Outline of the Geology of Norfolk,' 1833, and 'A Synoptical Table of British Organic Remains,' 1830, and about thirty other memoirs and works. 
While upon the subject of the evolution and extinction of lifeforms I may be permitted to refer you to a very able paper which has lately appeared," by Mr. C. B. Crampton, on this subject.

To-night I will only venture to glance at some of the INVERTE. 3RATA; leaving the VERTEBrata to be discussed upon another occasion.

"In the first place (Mr. Crampton writes) the lowly-organised groups have persisted in spite of the gradual evolution of more and more highly-organised forms, and this must be due in large measure to their rapid growth and reproductive powers.

(2) That groups appear to have a shorter range in time as they acquire a higher degree of organisation.

(3) That living forms of groups that are dominant at the present time rarely show ancestors of such great specialisation as themselves.

(4) That forms that are now isolated in their zoological affinities, and bordering on extinction, are generally highly specialised in some direction, but often show signs of degeneration, and usually have ancestors of greater specialisation during some former period of dominance. A few, at any rate, seem to show a smaller degree of fertility than might be expected.

(5) Other forms which have come down to us from a distant period with small amount of change, or with very graduallyacquired specialisation, often show a great power of resistauce to death. They are also generally extremely fertile.

(6) That extinct groups seem almost invariably to have acquired a great degree of specialisation during their period of dominance.

(7) That the more specialised genera and species of groups tend to have a shorter range in time than the less specialised, although they frequently appear to have temporarily acquired a greater dominance.

(8) When a group shows very quickly-acquired variation and specialisation its range is usually very restricted.

(9) That the later forms in extinct groups frequently show signs of degeneration, and sometimes a more primitive organisation than the most specialised forms, possibly owing their persistence to their slower specialisation.

(10) That long retention of primitive characteristics, or a great degree of stability and want of variation, has been usually associated with a long range in time.

(11) That higher groups do not spring from the most specialised forms of the parent groups before them in time, but from some generalised form in those groups which had retained a more primitive organisation."

- Proc. Roy. Phys. Soc. Edin., sir. p. 461; read March 20th, 1901. April 15th, 1903 


\section{TABLE OF STRATIFIED ROCKS.}

Shoving the range in time of the great groups of Animais, and the period during which each type was dominant.

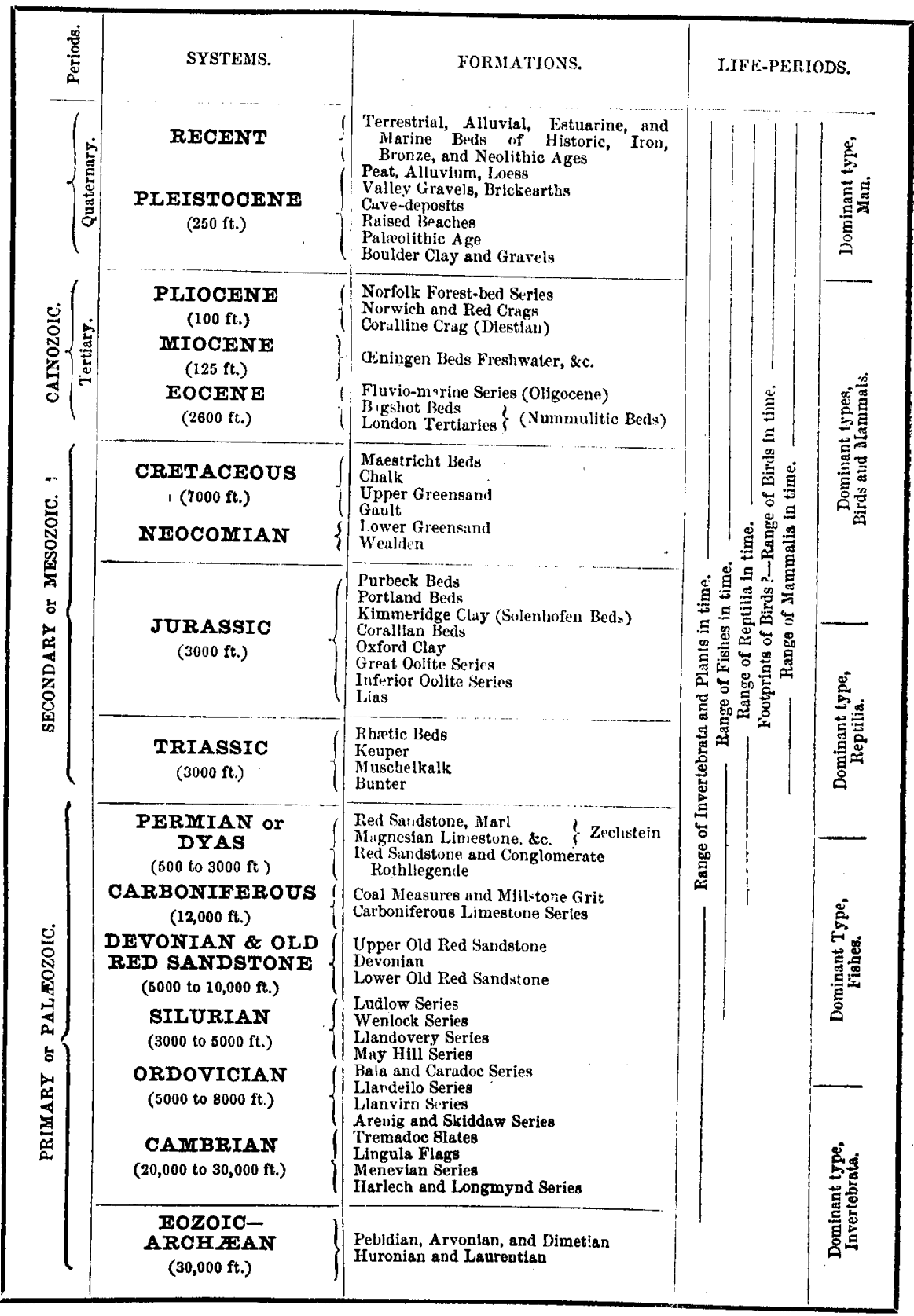


And I would add lastly :-

That those forms which have persisted through long past periods of geological time, have also an extremely wide geographical distribution at the present day. I illustrate this by a;diagram (fig. 34).

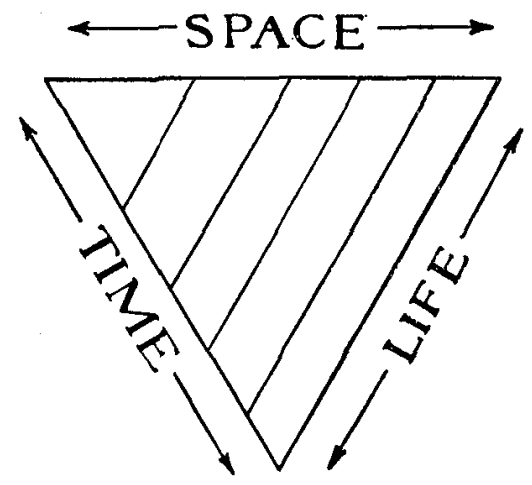

FIG. 34.

As might naturally be expected, it is the lowly-organised forms which show the longest geological history.

\section{PROTOZOA.}

RADIOLARIA are found throughout the whole geological series and are world-wide in their distribution.

- Of the ForaminiFERA, about two-thirds out of 2000 species occur fossil. The longevity of some genera is truly remarkable, e.g. Lagena, Nodosaria, Textularia. The first two range from Silurian, and the last from Carboniferous times to the present day. Fusulina and Schwagerina are world-wide in their distribution in Carboniferous time, forming entire beds of limestone. (They are, however, confined to the Carboniferous.) times.

Several giant species of Nummulina occur in early Tertiary

\section{PORIFERA (The Sponges).}

The Lithistid and Hexactinellid Sponges have existed since Cambrian times. The Calcispongice appear in late Palacozoic times and only become important in the Mesozoic period.

III. CELENTERATA :-I. HydrozoA.

The GRAPTOLITES are world-wide in their distribution in early Palreozoic time; they are enormously abundant and varied, and 
disappear at the end of the Silurian petiod. Dictyonema, a doubtfil Graptolite, extends from the Cambrian to the Devonian.

\section{CELENTERATA :-II. AnthozoA.}

Of the Conals, the Rugose and Tabulate corals are confined to he Palæozoic rocks.

The Hexacoralla are first seen in the Trias and continue to the present day. Zaphrentis, Petreice, Clisiophyllum and Strephodes, all simple types of Rugose corals, range from the Silurian to the Carboniferous age.

The same range is found for Cyathophyllum and Diphyphyllum, both of which are compound forms.

Of the Hexacoralla, four genera range from Jurassic to Recent.

Of the Tabulate corals (among the RuGosa), Fatosites and. Syringopora range from Silurian to Carboniferous times.

The existing corals belong to the Madreioraria, the Fusgida, and Perforata, and have no palrozoic representatives, but the Secondary and Tertiary deposits have yielded a large number of these forms. The composite Madrcpora include a vast number of forms and range from the Eocene to the present day.

\section{ECHINODERMA.}

Of the Echinoderma, the extinct groups the Crstords and Blastoids only lived in the Palrozoic period.

Of Cystoids, 50 genera and 250 species are known, and

Of Blastoids, 19 genera and 120 species are recorded.

The Crinords appear to have declined ever since their maximum development in Palæozoic times.

Ichthyocrinus ranges from the Ordovician to the Carboniferous.

Taxocrinus has the same range.

Of later forms, Pentacrinus, Extracrinus, and Antedon have persisted from the beginning of the Mesozoic period with very little change.

STARFISIIEs range from the Cambrian to the present day. Trias.

Echinoros : regular forms like Cidaris have existed since the

Echinocorys and some other irregular forms appear in the Cretaceous, but many of the genera quickly became extinct. But both regular and irregular forms have continued on to the present time.

$$
\text { V. POLYZOA ("SEA-Mats"). }
$$

The Polyzoa date back to the Ordovician.

Of Cyclostomata, Stromatopora and Berenicea range through the whole time to Ordovician. 
Many living genera range back into Mesozoic times.

The Monticuliporoids, a peculiar group, perhaps related to the PolyzoA, were dominant in Ordovician and Silurian times, but doubtfully survived the Palæozoic period.

Of the Cryprostomata, such genera as Fenestella, Polypora, Thabdomeson, and their allies are Palrozoic.

The Chilostomata, forming the bulk of living Polyzoa, date back to the Jurassic period.

\section{BRACHIOPODA.}

The Brachiopoda have their maximum development in Palæozoic times. Productus, Spirifer, Pentamerus, Cyrtia, Merista, Uncites, and Stringocephalus show not only great abundance and extraordinary specialisation of forms, but also remarkable variety of shape, size, and condition of their brachial supports. They have a comparatively short range in time, both in genera and species.

The long-winged Spirifers, dominant in the Devonian, were rapidly extinguished, but the simple Spirifor glabra ranges from the Devonian into the Carboniferous. Any striking peculiarity of growth or size seems to be followed by rapid extinction.

In the Mesozoic period both genera and species are much reduced in numbers, the forms chiefly belonging to the persistent Terebratula and Rhynchonella types, with slight variations in their shell markings.

With these are some exceptional forms, such as Lyra, Magas, Kingena, Trigonosemus - strictly Cretaceous, while a few others as P'ygope, Dictyothyris (specialised Terebratula), have a limited range in the Jurassic period.

From the Lower Palæozoic period genera like Lingula, Crania, and Discina have continued on, and are living now. Such forms may be truly termed persistent types.

In this division hermaphroditism (so rare in this class) occurs.

Lingula shows great resistance to death, surviving after being out of water and in a dry condition for some time.

\section{VERMES (WORMS).}

Worms being all soft-bodied animals are seldom found in a fossil state. Their former existence is, however, proved by their tracks, burrows, and castings which they have left in the sedimentary rocks from the Cambrian to the present day. Their chitinous teeth and jaws have been exhibited by Dr. Hinde, F.R.S., before this Society and described and figured in the Quart. Journ. Geol. Soc., London, 1879, 1880, and in the Transactions of the Royal Swedish Academy. 
Many species construct tubes. These variously formed cases (called Serpuloe) are common in many formations, but do not disclose much information about the structure of the animal itself.

They admirably illustrate the persistence in time of very simple and lowly organised forms, having bodies composed of a large number of similar segments (often capable of subdivision), and possessing moreover great powers of reparation and reproduction and resistance to death.

\section{MOLLUSCA.}

In the Mollusca, amongst the Lamellibranchiata, there are many persistent types showing very small amount of variation.

E.g. Solenomya has persisted since Carboniferous times, and Nucula from the Silurian onwards. Both belong to the "Protobranchiata" forms, with simple gills and a sole on the foot for creeping upon-not a mere digging foot.

In contrast to these are the Rudistes, such as Diceras, Upper Jurassic; Requienia, Monopleura, Caprina, Sphoerulites, and Hippurites, \&c., from the Cretaceous. These peculiar Molluses had a world-wide distribution, and occur in such numbers that beds of limestone are often built up of their shells. Chama, which represents them, has continued to the present day, but is less specialised.

Trigonia is not only a persistent genus, but exhibits great resistance to extreme variation, save in minor matters of shellornament. It ranges from the Trias to recent, and has a worldwide distribution. There are three species living in Australia and at least 100 species extinct.

In the SCAPHOPODA the curious tubular genus Dentalium ranges from the Ordovician to the present day. There are many species, but little variation from the type.

The multivalve Chitons extend also from Ordovician times to the present, but are never common in a fossil state. Only 70 species have been described from all known horizons. They are more abundant in modern seas, more than 200 species being now living.

The PTERopods (proper) only date back to the Cretaceous.

The earlier forms known as Tentaculites, Hyolithes, Conularia, are very doubtfully related to the Pteropoda. We have Tentaculites in Silurian and Devonian rocks; Hyolithes, Cambrian to Permian; and Conularia, from Ordovician to Lias ; both the latter are very persistent types.

In the Mollusch-Gasteropoda-Patella-like forms have existed from early Palæozoic times. Walcott has figured 6 species of Scenella, 8 species or varieties of Stenotheca, and 1 of Platyceras 
from the Lower Cambrian of North America. Capulus has persisted from Cambrian times to the present day.

The remarkable genus Pleurotomaria also ranges from Cambrian to recent, living in Japan and in the West Indies, and is represented by 4 or 5 species recent; 11 Tertiary; 575 Secondary; and 570 Palrozoic forms.

The Nerineido are very specialised shells in the structure of the columella; their range is also very briet. There are 150 species recorded from Mesozoic strata.

The Pulmonifera, Land-Snails range from the Coal Measures to recent.

Among the Cephaloroda, the Nautiloid type is remarkable for its persistence since Cambrian times. Many specialised forms, showing extreme variety of growth and shell-structure, have branched out from this stock during its dominance in Palæozoic times, but these have in turn all died ont.

Of these, the simple genus Orthoceras, with its long straight shell, had the greatest range, viz. from the Cambrian to the Trias; the other modifications have also fairly long ranges and show remarkable varieties of shell-structure.

The Ammonites, which range from the Trias to the Chalk, show almost endless variety in shell-ornament within certain limits, and have a world-wide range in Jurassic times branching out into more than 600 species.

In the Cretaceous period (before their disappearance) they put on most singular and remarkable developments of shell-variation, Crioceras, Scaphites, Ancyloceras, Hclicoceras, Toxoceras, Baculites, Ptychoceras, Hamites, Turrilites, then they disappear entirely. We do not know the animal in Ammonites.

The Belemnitidce range from the Trias to ths Cretaceous.

The guard in most genera is large and dense, whilst the chambered portion or "phragmocone," is small and rudimentary. But Aulacoceras of the Trias has a large phragmocone and the guard quite sinall.

The Belemnites appear to have been gregarious (like their modern congeners the "Squids"), entire beds in the Lias being composed of their guards at Whitby, Yorkshire, Lyme, in Dorsetshire, and other localities in the central counties. More than 100 species have been described.

Possibly Spirulirostra, of the Tertiaries, and the recent Spirula may be survivors which have gradually dispensed with the guard to the shell, so characteristic of the Belemnites proper.* time.

The following table shows the range of the Arthropoda in

* I am desirous to mention here that for the above summary, from the Protozos to the Molusson, I have largely made use of Mr. C. B. Crampton's statistics with some modifications fiom my own yotes and other sources of information.-H. W. 


\section{ARTHROPODA.}

\section{A. Crustacea.}

\section{ENTOMOSTRACA. 1. Braxchopoda.}

Order 1. Phyllopoda.

2. PHYLLOC IRIDA.

Hymenocaris,

Ceratiocaris $\left(\right.$ Nebalia $\left.{ }^{*}\right)$. . Ditto.

Estheria

Cheirocephalius

\section{Artemia}

Cambrian to recent

Daphnia and its nllics

Devonian to recent.

'Tertiary to recent (Fresh-water).

\section{ADOCEMA.}

- Daphria

The Ephippia winter egres of Daphnia have been found tossil in

4. Ostracoda. the For'st Bed scries of Norfolk.)

Cypris, Candona, Cythere, Sc. - P..lreozoic to recent.

5. Copepoda.

Cyclope, de. . . . Not found fosil

Miny other families ure uut represented in a fossil state.

1I. MAI.ACOSTRACA.

1. Podophthalma.

Brachyura

Macrura

Selizopoda

Stomapoda

2. Ennonitualia.

Cumacea
Isopoda
Przarcturus
Amphipoda.
Jurngsic to rccent.

Carboniferous to recent.

Ditto (Palæocaris).

Devorian or Silurian to. recent.

Carboniferous to recent.

Magn. L. to secent.

Devolliall?

Carbouiferous?

III. GIo:s:osmold Hackel.

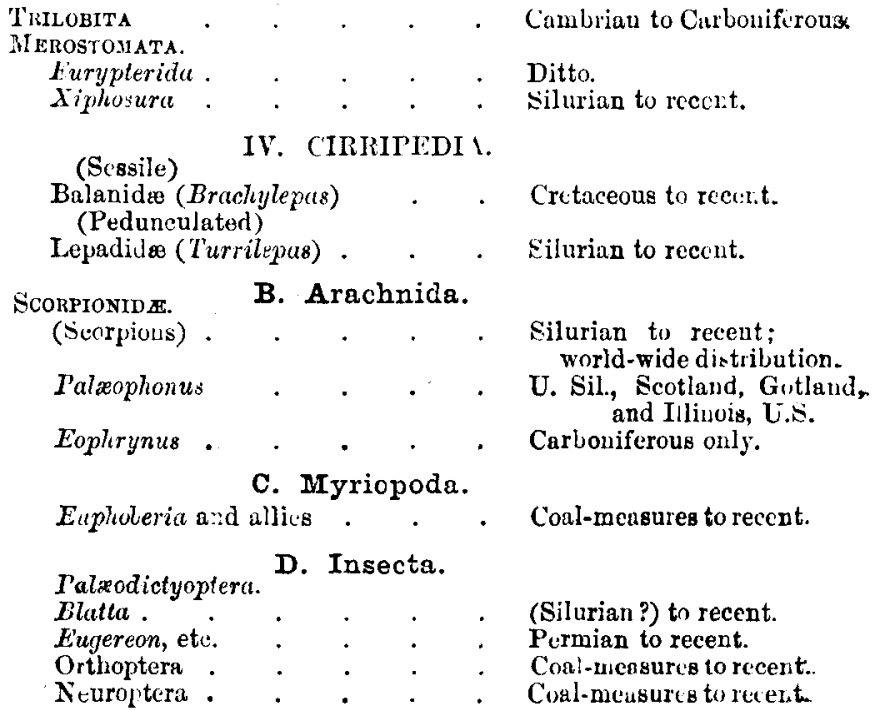

* Hecent analogue. Probable progeritor of Decal oda. 


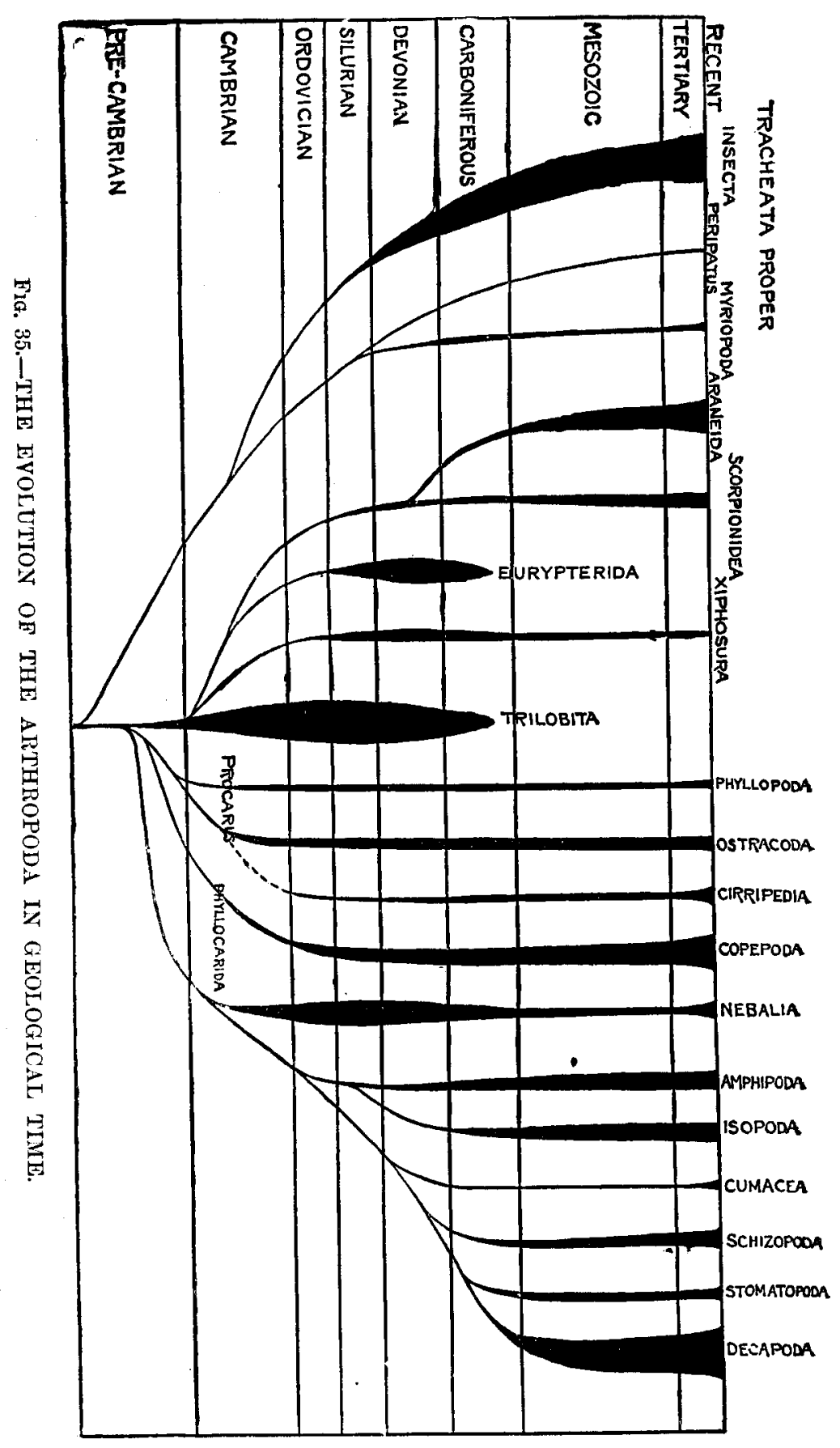


The diagram (fig. 35) on the preceding page (p. 153) is intended to convey an idea of the probable evolution of the Arthropoda in geological time.

\section{Summary.}

And now, "let us hear the conclusion of the whole matter."

The whole history, since the beginning of life on the earth, shows a steady upward tendency (in fact Evolution) in life as displayed in the Geological Record.

\section{Extinct Groups.}

Some forms appear, attain a more or less important position on Life's Stage, and then die out completely.

Of such are the once abundant Graptolites, which had their beginning in the Cambrian, their maximum in the Ordovician and Silurian, and then disappeared.

The Trilobites, which began in the Cambrian, attained their maximum in the Silurian, lived on into Carboniferous times, and then disappeared.

The Merostomata (Ptery,otus, Eurypterus, Stylonurus, \&c.) began in the Silurian, attain $\cdot d$ their maximum, lived on into the Devonian and Carboniferous periods, and then became extinct.

\section{Persistent Groups.}

Again we have persistent forms of which we seem to see neither the beginning nor the ending.

Of these we may name the Protozoa, embracing the RADIOLARIA and the FORAMINIFERA, both persistent in rocks of all ages and well represented at the present day.

The Porifera (Sponges) which, though materially differentiated in the course of geological ages, have lived on till to-day.

The CRINordea (Sea-lilies), represented from Silurian times to the present day, but not nearly so abundant as in Palæozoic times.

The Starfishes (Asteroidea and Ophiuroidea), both persistent types from Silurian (or earlier) times to the present.

The Annelida again are met with in all strata and also living.

The Brachiopoda, beginning in the Cambrian, enormously developed in Silurian, Devonian, Carboniferous, and Secondary deposits, and still surviving in diminished numbers in modern seas.

Mollusca, represented in past time ly the persistence of

Cambrian to recent.

Sraphopoda

Cumbrian? to recent.

Chitonida

Silurian to recent.

Pteropoda

Cretaceous to recent.

Prosobranchiata

Cambrian? to recent.

Cephalopoda (in part)

Ordovician to recent.

Pulmonifera (Zunites and Pupa)

Coal-measures to reoent. 
The Crustacea, represented in past time by persistent forms such as the

Extomostraca-

Ostracoda

Phyllocaritia

(Xiphosura) Limulus

The Arachnida.

Scorpionida (Scorpio) . . . . Silurian to present day.

The Myriopoda .

The Insecta.

Neuroptera
Orthoptera
Thysantra
Homoptera

Of Never Groups.
Cambrian to recent.

Silurian to rec'ent.

Coal-measures to recent.

Conl-measures to recent.

" $"$
," ",

The following groups which have appeared in newer geological time may be cited-

The Bryozoa

The Echinoidea, or "Sea-urching"

The Pteropoda (proper)

Tise Gasteropoda

The liecapoda

The Isopoda, \&c. from Carbonif-rous to recent.

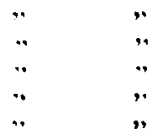

And the great mass of living Insecte, from the Secondary to receut.

The Range in time of the principal groups of the Invertebrata is given in a diagram form on p. 156, showing the Persistent groups (P.), the Extinct groups (E.), and the comparatively Modern groups (M.).

If we except such groups as the Crinoids, the Brachiopods, the Nautilidæe, the Xiphosura-which evidently attained their greatest maximum in the past, and although still surviving are now but a feeble folk-we shall notice that the modern Echinoids, Bryozoa, Mollusca, Gasteropoda (Siphonostomata and Pulmonifera); the higher Crustacea (Decapoda, Brachyura, and Macrura) the Isopoda, Stomapoda, \&c.; and our modern Insects, are far in advance of their "forbears" as regards development, and this is especially true of all the higher forms of life.

Just as in the Vegetable world our modern Flora (with its wealth of Flowering plants) is far more highly organised, varied and beautiful than in the past ages of the world, so is the associated Fauna of to-day when contrasted with that of the past.

But, it may be asked, what prospect is there of arriving at the earliest known ancestor from which all these varied forms have been derived? What help does the geological record afford us ? My duty, as your guide, is to inform you that our increased knowledge of the older rocks has not shown that we are nearer the fulfilment of the young biologist's dream, and the secret of Pandora's Box remains still undiscovered. We have not as yet reached the beginning of life. 





In the oldest Cambrian of North America, Prof. C. D. Walcott has shown the presence of some 61 so-called genera and 142 reputed species, embracing Sponges, Corals, Annelids, Graptolites, Echinoderma, Brachiopoda, Mollusca, lowly Crustacea, and Trilobites. But, after all our labours, and strivings to reach the beginning of all things, let us take comfort in this, that, like Pandora of old, we still have Hope left us in the Box (or shall we say in the Rocks?).

Those Eozoic Rocks (see p. 146) which underlie our present oldest fossiliferous strata, may yet yield to the geologist and biologist in the future, an earlier and more primitive fauna and flora, just as the Lower Cambrian rocks have done for us in the past.

Note.-Prof. C. D. Walentt, in his monograph on the Lower Cambrian or "Olenellus Zone" of North America, gives the following list of fossils:-

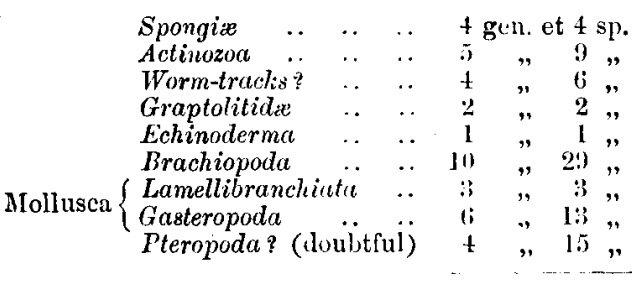

$$
\begin{aligned}
& \text { Crustricece - }
\end{aligned}
$$

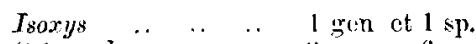

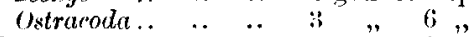

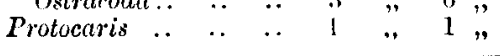

$$
\begin{aligned}
& \begin{array}{l}
\text { Trilobitt - } \\
\text { Agnostus }
\end{array} \text {.. } \quad . \quad . \quad . \quad 1 \text { gen. et } 3 \text { sp. } \\
& \begin{array}{lllll}
\text { Agnostus .. } & \text {.. } & \text {.. } & 1 \text { gon. et } 3 \text { sp. } \\
\text { Mirrodisew: } & \text {.. } & \text {.. } & 1 \text { 1 } & 8 \text {, }
\end{array}
\end{aligned}
$$

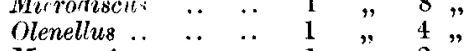

$$
\begin{aligned}
& \begin{array}{llllll}
\text { Mesonacis.. } & . . & . . & 1 & \text { " } & 2 \%
\end{array} \\
& \text { Holmia .. }
\end{aligned}
$$

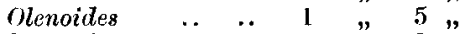

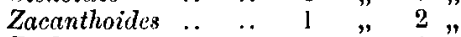

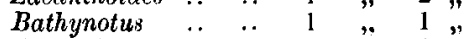

$$
\begin{aligned}
& \text { Avalonia .. }
\end{aligned}
$$



$$
\begin{aligned}
& \begin{array}{lllll}
\text { Ptychoparic .. } & \text {. } & 1 & \text { " } & 8
\end{array} \\
& \text { Crepicephalus .. } \quad . . \quad 1 \quad \text { " } 2 \text { " } \\
& \text { Oryctocephalus .. } 1 \text { " } 1 \text {, } \\
& \text { Anomocare .. } . .11 \text { " } 1 \text {, }
\end{aligned}
$$

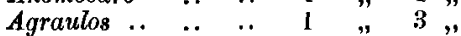

$$
\begin{aligned}
& \begin{array}{lllllll}
\text { Protypus .. } & . . & . & & \text { 1 } & 3 & 3
\end{array}
\end{aligned}
$$

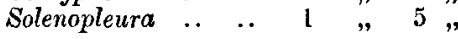

$$
\begin{aligned}
& 5 \text { gen. et } 8 \mathrm{sp} \text {. } \\
& 39 \text { gen. et } 82 \mathrm{sp} \text {. }
\end{aligned}
$$

